\title{
The point on Opaliopsis atlantis (Gastropoda: Epitoniidae) distribution: new data from the Mediterranean and implications
}

\author{
Salvatore Giacobbe ${ }^{1} \&$ Walter Renda ${ }^{2}$ \\ ${ }^{1}$ Università degli Studi di Messina (UNIME), Dipartimento di Scienze Chimiche, Biologiche, Farmaceutiche ed Ambientali (CHIBIOFARAM). \\ Messina, Italia. ORCID: http://orcid.org/0000-0002-4619-4862. E-mail: sgiacobbe@unime.it \\ 2 Private researcher. Amantea, Italia. ORCID: http://orcid.org/0000-0003-3944-6758. E-mail: w.renda1@tin.it (corresponding author)
}

\begin{abstract}
Specimens of the rare amphi-Atlantic epitoniid Opaliopsis atlantis have been recorded in the Strait of Messina (central Mediterranean) from a hydrozoan stylasterid-rich habitat. The record, which adds a new site to the sporadic occurrences of this prevalently deep-water species, may be considered the first contextualized report from Mediterranean Sea. Opaliopsis atlantis displays a planktotrophic larval development functional for long-range colonization of favorable habitats. Its discontinuous distribution all over its broad geographic range highlights the potential role of Atlantic seamounts as stepping-stones for transoceanic dispersal. Although no conclusive information is yet available upon the feeding requirements of 0 . atlantis all over its range, we suggest that this cnidarian-ectoparasitic prosobranch could adapt to different hosts, as a strategy that may enhance its wide biogeographic distribution.
\end{abstract}

Key-Words. Epitoniidae; Amphi-Atlantic; Mediterranean; Bathyal; Biogeography.

\section{INTRODUCTION}

Opaliopsis atlantis (Clench \& Turner, 1952) belongs to a kind of epitoniids provided with a multispiral and ribbed planktotrophic larval shell. This morphologically distinct deep-water group, previously placed in the subfamily Nystiellinae Clench \& Turner, 1952, was then elevated to family level by Nützel (1998), until subsequent biomolecular studies did not validate their separation from Epitoniidae (Takano \& Kano, 2014; Bouchet \& Rocroy, 2017). The planktotrophic development, involving a high dispersal ability (Bouchet \& Warén, 1986), accounts for the number of "nystiellids" displaying an amphi-Atlantic distribution (Lima \& Christoffersen, 2013). Originally described upon few specimens from Cuba and Florida, O. atlantis was reported also off Brazil (Andrade et al., 2011; Lima \& Christoffersen, 2013). To the east, O. atlantis is known from Azores, Madeira and Gibraltar (Bouchet \& Warén, 1986; de Frias Martins et al., 2009; Segers et al., 2009; Gofas et al., 2014) up to the Mediterranean (Smriglio \& Mariottini, 1999; Mifsud, 2009; Manousis et al., 2018). O. atlantis is one of the most uncommon epitoniids, known thus far from a handful of live specimens and a few empty shells all over its range. The finding of two specimens from the Strait of Messina (central Mediterranean) improves our knowledge on the areal of this rare species and suggests some considerations on its ecology.

\section{MATERIAL AND METHODS}

Samplings were carried out in July-August 1995 by means of modified Van Veen grab $\left(0.25 \mathrm{~m}^{2}\right.$ sampling surface) and triangular dredge $(60 \mathrm{~cm}$ mouth opening), according to the expected sea-floor nature. Samples were washed on board, under a gentle seawater flow throughout $1 \mathrm{~mm}$ mesh sieve, and residues fixed in alcohol $70 \%$. The living fauna was sorted in laboratory under a stereomicroscope, while the residual sediment was dried at room temperature. A first specimen of $O$. atlantis (Messina University; repository code: BEL145POP'95FRAN1) was found in a crab sample from a steep canyon head belonging to the Gioia Basin system (Longhitano, 2018), north-east sector of Messina Strait (St. FRAN1; 38 $22^{\prime} 26.83^{\prime \prime} \mathrm{N}, 1^{\circ} 37^{\prime} 40.40^{\prime \prime} \mathrm{E}$; $389 \mathrm{~m}$ depth). Soft tissue remains recognizable throughout the shell aperture were extracted and examined under stereomicroscope. A second specimen (Coll. Renda, Amantea; repository code: CWR145POP'95RAN10) was found in the residue from the sample RAN10 (38 $\left.14^{\prime} 58^{\prime \prime} \mathrm{N}, 15^{\circ} 37^{\prime} 37^{\prime \prime} \mathrm{E}\right)$, from 110 to $80 \mathrm{~m}$ depth, dredging a vertical cliff in the "Sill", a site located transversely to the Strait in 
its narrowest point and characterized by rough topography with pinnacles (Longhitano, 2018) (Fig. 1).

Abbreviations: BEL = Benthic Ecology Laboratory, University of Messina, Italy; CFS = Collection Franck Swinnen; CWR = Collection Walter Renda, Amantea, Cosenza, Italy; CWS = Collection Willy Segers; $\mathbf{M C Z}=$ Museum of Comparative Zoology, Cambridge, USA; MMF = Museu Municipal do Funchal, Madeira, Azores; MNRJ = Museu Nacional/Universidade Federal do Rio de Janeiro, Rio de Janeiro, Brazil; MZSP = Museu de Zoologia/
Universidade de São Paulo, São Paulo, Brazil; USNM = National Museum of Natural History, Washington, DC, USA; ZMA = Zoologisch Museum Amsterdam.

\section{RESULTS}

The specimen from station RAN10 (Figs. 2A-C, 3A-B) was found associated to almost $2 \mathrm{dm}^{3}$ biogenic coarse residue, consisting of fragments of the stylasterid Errina aspera (Linnaeus, 1767) infested by the ectoparasite gas-

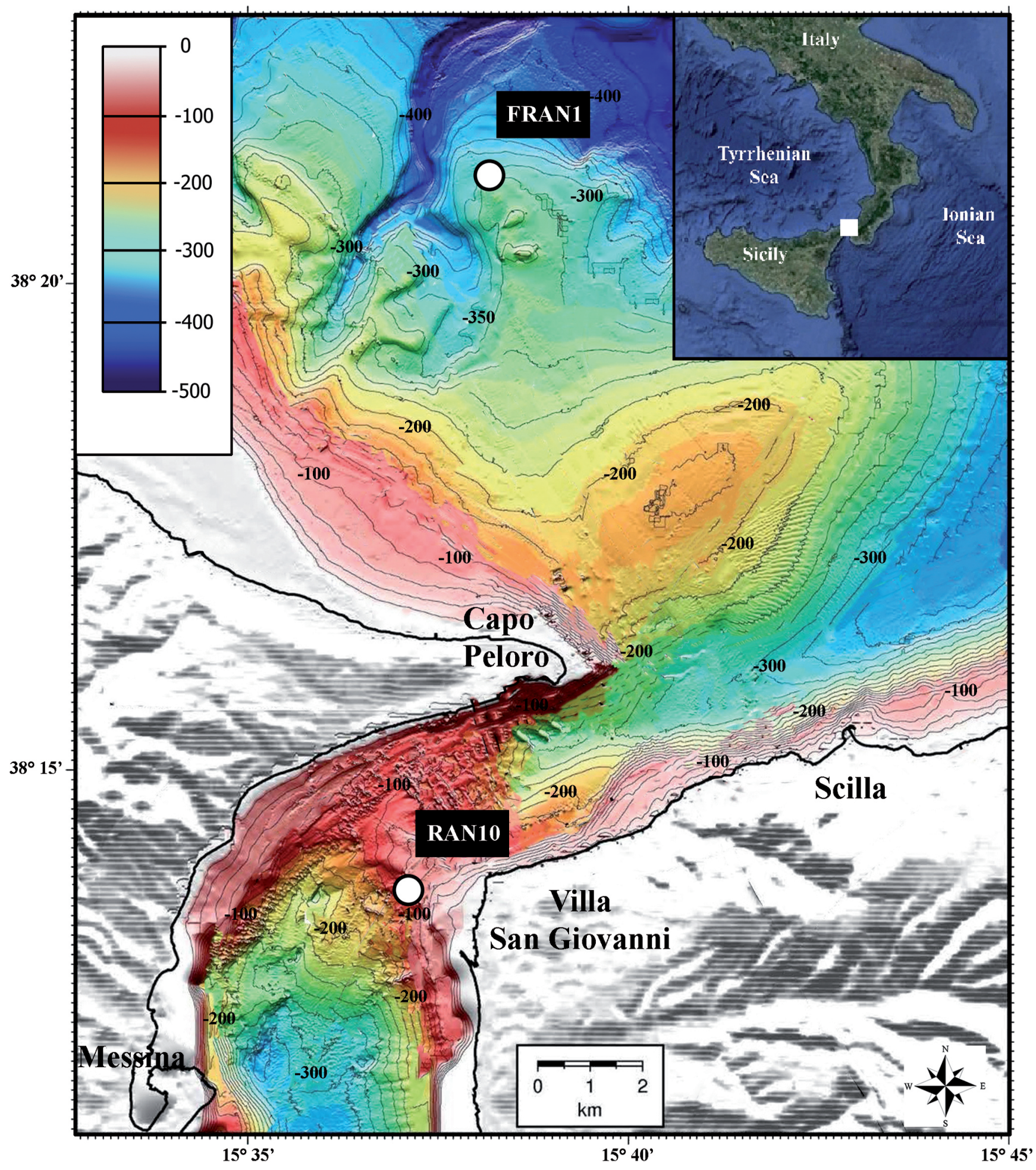

Figure 1. Bathymetric map of the northern Messina Strait (modified from Doglioni et al., 2012). The two 0. atlantis sampling stations are indicated. 
tropod Pedicularia sicula Swainson, 1840. The specimen, lacking the protoconch, measured $9.0 \mathrm{~mm}$ in teleoconch length.
The specimen from station FRAN1 (Figs. 2D-F, 3C-D) was found associated to a biostromal framebuilding formed by deep-sea oysters, Neopycnodonte cochlear
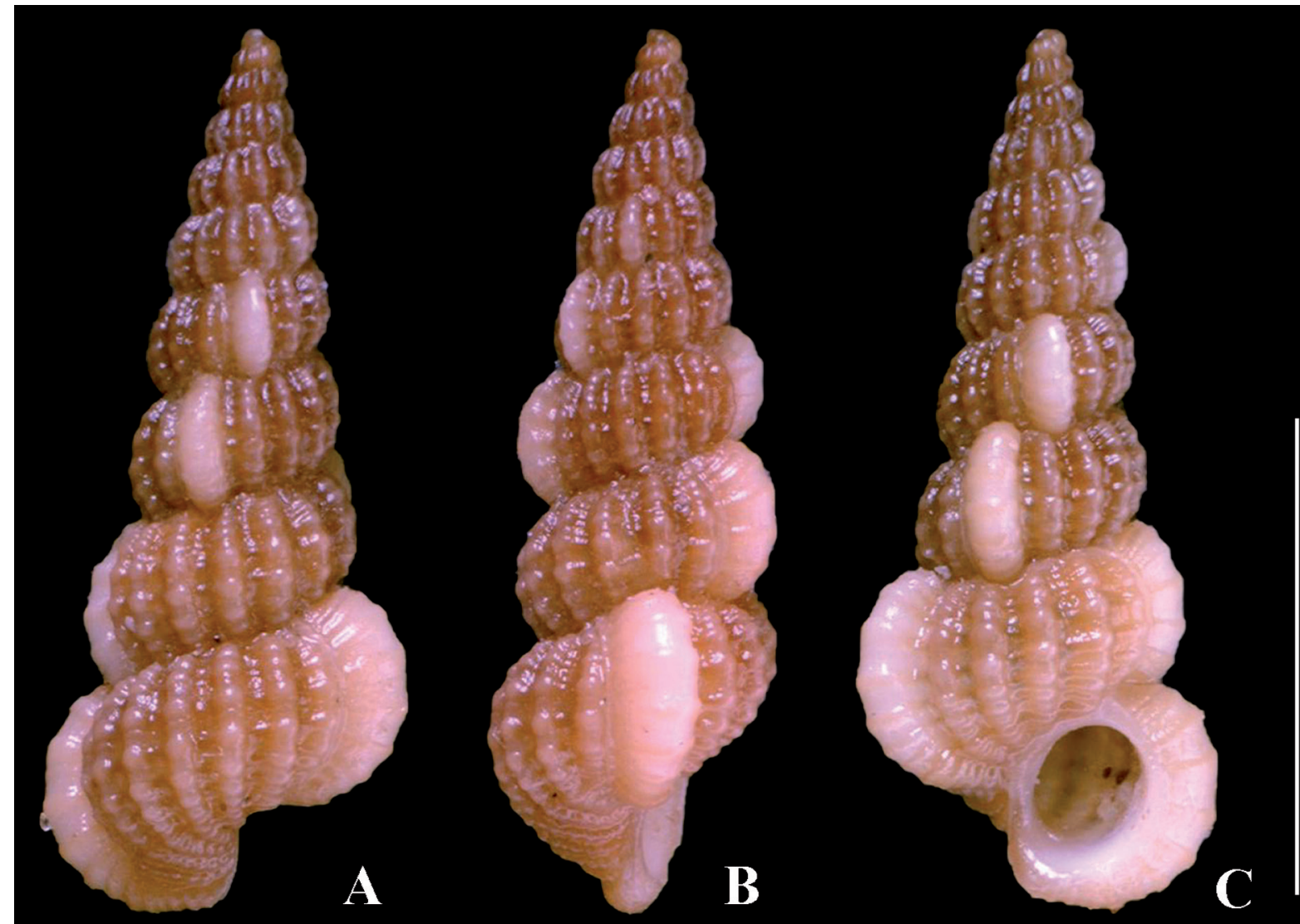

$5 \mathrm{~mm}$
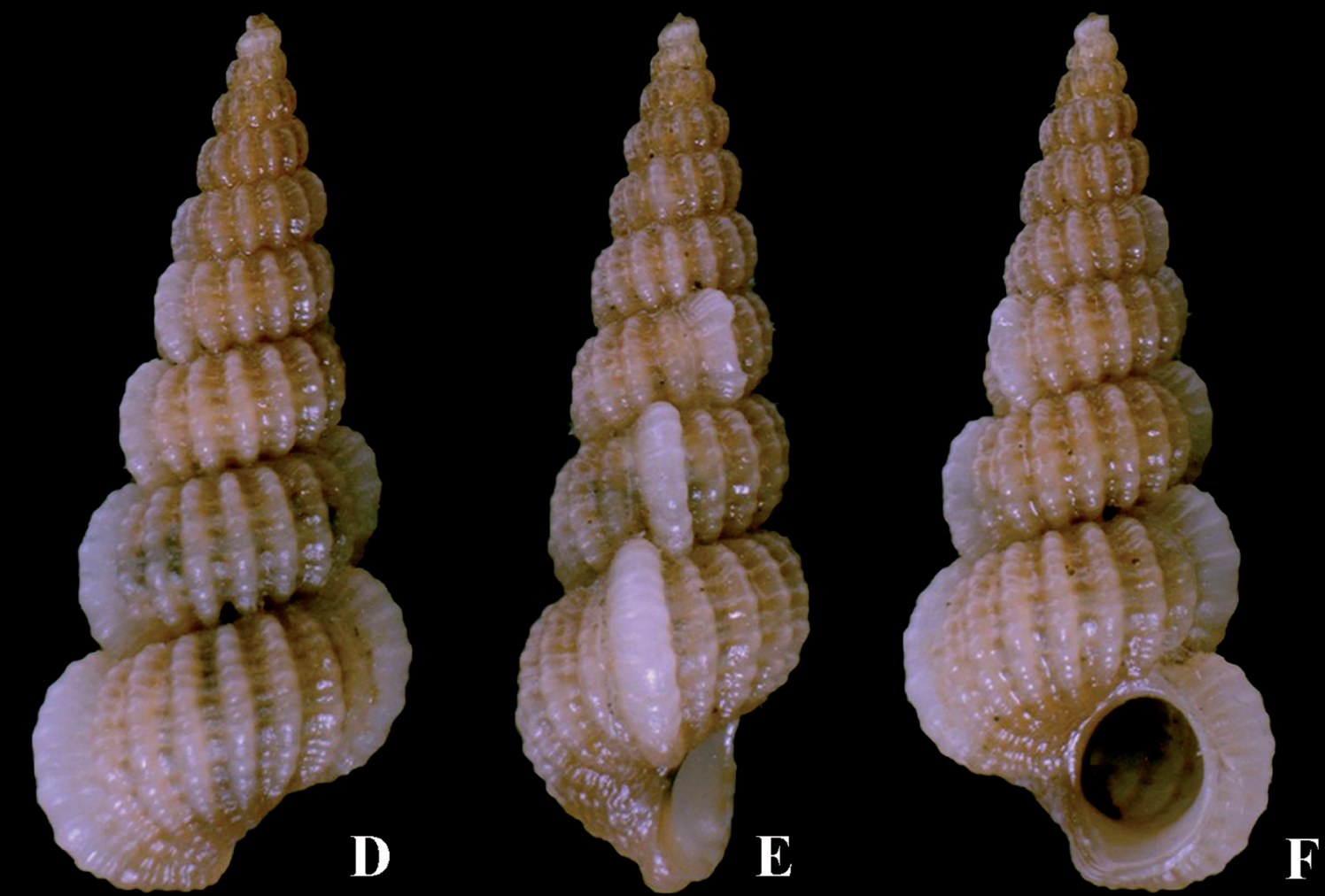

Figure 2. (A-F) Opaliopsis atlantis: (A-C) Shell from Station CWR145POP'95RAN10, height $9.0 \mathrm{~mm}$. (D-F) Shell from Station BEL145POP'95FRAN1, heigh $8.4 \mathrm{~mm}$. 
(Poli, 1795). The specimen, also lacking in protoconch, measured $8.4 \mathrm{~mm}$ in length. The organic matter found inside the shell, lacking operculum as well as other recognizable tissues, might belong to sipunculid remains.

\section{DISCUSSION}

The scant information available on 0 . atlantis mostly refers only on a generic geographic location. For instance, general information about depth and geographical coordinates has been provided for holotype and paratypes, with the indication "off Lantana in 83 fathoms" of McGinty collection paratype. Nothing is reported about habitat and specimen condition, although the original description, reporting operculum features, suggests that the type at least was collected alive (Clench \& Turner, 1952). Other West Atlantic reports, only providing depth and geographical coordinates, concerned empty shells from Brazil (Andrade et al., 2011). To the east, the statement "The species may be still living in the E. Atlantic" by Bouchet \& Warén (1986) about their record from Azores implies that the specimen was not collected alive (some inaccuracy on the BALGIM 153 position was later clarified in Bouchet \& Taviani, 1989). Further records of dead specimens and fragments by Brenke (2002), Segers (2009), de Frias Martins et al. (2009), were occasionally supported by depth and/or geographic position (Table 1).

In the Mediterranean, more information is given by Bouchet \&Warén (1986) which hypothesize that their contextualized records from Gibraltar and Alboran pertain to last glacial (Würmian) submarine deposits. Sporadic
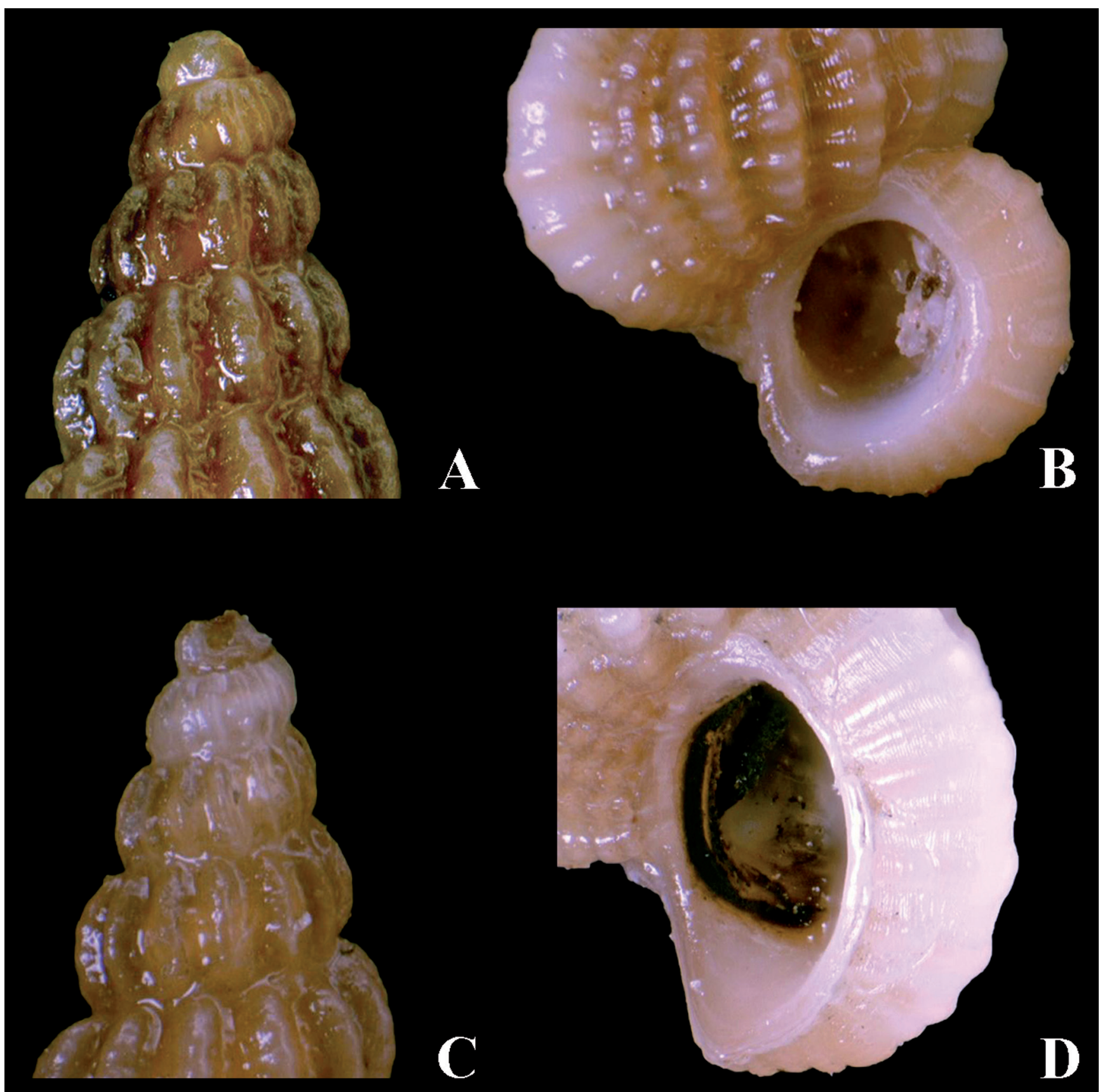

Figure 3. (A-D) Opaliopsis atlantis, details of apex and aperture. (A-B) CWR145POP'95RAN10; (C-D) BEL145P0P'95FRAN1. 
Table 1. Synoptic table of 0 . atlantis reports from scientific literature. Geographical coordinates and depths are reported according to the original data.

\begin{tabular}{|c|c|c|c|c|c|c|}
\hline Code & spm & Locality & Position & Depth m & Reference & Additional data \\
\hline \multicolumn{7}{|c|}{ West Atlantic } \\
\hline \multirow[t]{2}{*}{ MCZ 187988} & 1 alive & Bahia de Cochinos, Cuba & $22^{\circ} 09^{\prime} \mathrm{N}-81^{\circ} 10^{\prime} \mathrm{W}$ & $420-484$ & Clench \& Turner, 1952 & Holotype \\
\hline & 1 & Lantana, Florida & & 152 & Clench \& Turner, 1952 & Paratype - McGintypriv. coll. \\
\hline USNM 417386 & 1 & Key West, Florida & & 115 & Clench \& Turner, 1952 & Paratype - Eolis station 43 \\
\hline USNM & 1 & Key West, Florida, USA & & 118 & Clench \& Turner, 1952 & Paratype - Eolis station 321 \\
\hline MNRJ 13617 & 1 & Ceará, Brasil & $02^{\circ} 14^{\prime} 25^{\prime \prime} \mathrm{S}-38^{\circ} 22^{\prime} 50^{\prime \prime} \mathrm{W}$ & $240-260$ & Andrade et al., 2011 & \\
\hline MZSP 67621 & 1 & Ceará, Brasil & $02^{\circ} 14^{\prime} 25^{\prime \prime} \mathrm{S}-38^{\circ} 22^{\prime} 50^{\prime \prime} \mathrm{W}$ & $240-260$ & Andrade et al., 2011 & \\
\hline MNRJ 15499 & 1 & Pernambuco, Brasil & & 690 & Andrade et al., 2011 & \\
\hline MNRJ 13615 & 1 shell & Santa Catarina, Brasil & $26^{\circ} 38^{\prime} 44.9^{\prime \prime} \mathrm{S}-06^{\circ} 51^{\prime} 54.2^{\prime \prime} \mathrm{W}$ & 150 & Andrade et al., 2011 & \\
\hline \multirow[t]{4}{*}{ MNRJ 13613} & 1 & Santa Catarina, Brasil & $26^{\circ} 38^{\prime} 44.9^{\prime \prime} \mathrm{S}-46^{\circ} 51^{\prime} 54.2^{\prime \prime} \mathrm{W}$ & 150 & Andrade et al., 2011 & \\
\hline & \multicolumn{3}{|c|}{ East Atlantic } & & & \\
\hline & 1 shell & Azores & $37^{\circ} 35^{\prime} \mathrm{N}-25^{\circ} 32^{\prime} \mathrm{W}$ & $810-825$ & Bouchet \& Waren, 1986 & BIACORESexpedition ST 240 \\
\hline & & Gran Meteor Banck & $30^{\circ} 00^{\prime} \mathrm{N}-28^{\circ} 30^{\prime} \mathrm{W}$ & & Brenke, 2002 & Meteorexpedition M42/3 \\
\hline MMF 33280 & 1 shell & Madeira & & 54 & Segers et al., 2009 & SEPLAT expedition st 133 \\
\hline CFS & 1 shell & Madeira & & & Segers et al., 2009 & SEPLAT expedition st 133 \\
\hline CWS & fragment & Porto-Novo, Madeira, & & 364 & Segers et al., 2009 & \\
\hline \multirow[t]{11}{*}{ ZMA } & fragment & Deserta Grande & & 120 & Segers et al., 2009 & CANCAP expedition st 1017 \\
\hline & 1 shell & Azores & $37^{\circ} 41^{\prime} 34^{\prime \prime} \mathrm{N}-25^{\circ} 27^{\prime} 34^{\prime \prime} \mathrm{W}$ & $167-189$ & de Frias Martins et al., 2009 & \\
\hline & \multicolumn{3}{|c|}{ Mediterranean } & & & \\
\hline & 4 (würmian?) & Strait of Gibraltar & $35^{\circ} 53^{\prime} \mathrm{N}-06^{\circ} 33^{\prime} \mathrm{W}$ & $518-524$ & Bouchet \& Waren, 1986 & BALGIM expeditionDR49 \\
\hline & 1 (würmian?) & Strait of Gibraltar & $35^{\circ} 53^{\prime} \mathrm{N}-06^{\circ} 32^{\prime} \mathrm{W}$ & $518-526$ & Bouchet \& Waren, 1986 & BALGIM expeditionDW50 \\
\hline & 1 (würmian?) & West Alboran Sea & $35^{\circ} 56^{\prime} \mathrm{N}-05^{\circ} 35^{\prime} \mathrm{W}$ & $568-604$ & Bouchet \& Waren, 1986 & BALGIM expedition DR153 \\
\hline & 2 shells & Alboran Sea, Spain & $36^{\circ} 21.06^{\prime} \mathrm{N}-03^{\circ} 58.07^{\prime} \mathrm{E}$ & $349-365$ & Gofas et al., 2014 & DEEPER 04/09 cruise \\
\hline & 1 shell & Central Tyrrhenian Sea & $41^{\circ} 24^{\prime} \mathrm{N}-12^{\circ} 03^{\prime} \mathrm{E}$ & $500-600$ & Smriglio \& Mariottini, 1999 & Private collection \\
\hline & 2 shell & Malta & $35^{\circ} 56^{\prime} \mathrm{N}-14^{\circ} 19^{\prime} \mathrm{E}$ & $140-160$ & Mifsud, 1993 & \\
\hline & 1 dead & Malta & $35^{\circ} 57.934^{\prime} \mathrm{N}-14^{\circ} 10.706^{\prime} \mathrm{E}$ & 550 & Mifsud, 2009 & \\
\hline & 1 alive, 5 shells & North Aegean & & $200-400$ & Manousis et al., 2018 & \\
\hline BEL145POP'95FRAN1 & 1 dead & Strait of Messina, Italy & $38^{\circ} 22^{\prime} 26.83^{\prime \prime} \mathrm{N}-15^{\circ} 37^{\prime} 40.40^{\prime \prime} \mathrm{E}$ & 389 & Present paper & POP'95 expedition St. FRAN1 \\
\hline CWR145POP'95RAN10 & 1 dead & Strait of Messina, Italy & $38^{\circ} 14^{\prime} 58^{\prime \prime} \mathrm{N}-15^{\circ} 37^{\prime} 37^{\prime \prime} \mathrm{E}$ & $80-110$ & Present paper & POP'95 expedition St. RAN10 \\
\hline
\end{tabular}

dead specimens have been reported as associated with continental slope bioconstructions at 500-600 m depth (Smriglio \& Mariottini, 1999) and Leptometra community (Gofas et al., 2014; see figure in Rueda et al., 2019), respectively from the Tyrrhenian Sea and the Alboran Sea. Depth and generic indications of "rocky and coralliferous" habitats are given by Manousis et al. (2018), about occasional records of one living specimen and five shells from North Aegean. More important, the occasional record of a living specimen from Malta's continental slope with "fossil" deep water corals (Mifsud, 2009) documents that 0 . atlantis in the Mediterranean is ectoparasitic on the actinarian Actinauge richardi (Marion, 1882).

Such host-parasite relationship, however, seems limited to the situation observed in the Strait of Messina, where the habitat of $A$. richardi (Pierdomenico et al., 2019) overlaps that of $O$. atlantis, whilst this actinarian is unknown in the west Atlantic fauna. A potential implication is that $O$. atlantis is not strictly species-specific, suggesting that, similarly to other ectoparasites, it is not tied to a peculiar habitat, but could exploit other cnidarians in its geographic range. Nothing however is known about the West Atlantic habitat of O. atlantis, except for the bathymetric range that agrees with the Mediterranean records (Table 1).

Opaliopsis atlantis is also known as fossil in lower circalittoral to bathyal Pleistocene deposits facing the Strait of Messina (Crovato \& Taviani, 1985), as well as in nearby north-eastern Sicily (Di Geronimo et al., 2005). As far as concerns the amphi-Atlantic distribution of 0 . atlantis, first comments are given by Crovato \& Taviani (1985), which favor the hypothesis of a Mediterranean settlement by vertical migrating larvae rather than through a step-by-step bottom colonization. Such a hypothesis is consistent with the recognized ability of some tropical gastropod species to ensure an amphi-Atlantic distribution by means of long-living teleplanic larvae. The planktotrophic development, moreover, has been indicated as a functional adaptation in prosobranch gastropods inhabiting transient habitats such as sunken wood and hydrothermal vents, more in general seeming most suited for exploitation of patchy but widespread habitats (Jablonski \& Lutz, 1983).

At least two Amphiatlantic-Mediterranean coralliophilinae ectoparasitic on deep water corals, Coralliophila richardi (Fischer, 1882) and Babelomurex sentix (Bayer, 1971), similarly, illustrate the role of the seamounts as stepping-stones in transoceanic dispersal (Oliverio \& Gofas, 2006). The physiographic setting of the seamounts, in this respect, plays a fundamental role, due to little sedimentary input and extensive hard bottoms in the bathyal, similarly to the Messina Strait environment (Longhitano, 2018). Regarding C. richardi, Taviani et al. (2009) suggest its status of permanent resident in the western Mediterranean, in accordance with "its prolonged, albeit not necessarily continuous, presence 
in this basin since the Early Pleistocene". A situation somehow analogous for $\mathrm{O}$. atlantis, whose presence in the Strait of Messina area is documented since the Pleistocene (Crovato \& Taviani, 1985).

The scattered records of $O$. atlantis, covering a wide bathymetric range, concern different benthic assemblages that include the here reported oyster beds and bathyal stylasterids Errina aspera, a peculiar habitat that the Strait of Messina shares with Gibraltar and, throughout the vicariant $E$. dabneyi (Pourtalès, 1871), with the East Atlantic Azores islands (Braga-Henriques et al., 2011).

\section{CONCLUSION}

The present records in the Strait of Messina confirm further the amphi-Atlantic distribution and basinal-wide occurrence of $O$. atlantis in the Mediterranean Sea. The report, which after Bouchet \& Warén (1986) and Gofas et al. (2014) for Gibraltar and Alboran, is the first to arise from a planned investigation, rather than from occasional records, suggests that this species is not an occasional visitor from the Atlantic Ocean as it has been hypothesized for most deep-sea gastropods (see Bouchet \& Taviani, 1989). Opaliopsis atlantis, instead, should be considered a component of the Mediterranean fauna since long (Pleistocene), as testified by its fossil record in this basin.

The planktotrophic larval development in principle permits the distribution of this species over a wide geographic range accounting for its presence in the western Atlantic. The few eastern Atlantic records refer to seamounts underlining their role as stepping-stones for prosobranch amphi-Atlantic dispersal (Leal \& Bouchet, 1991; Brenke, 2002), up to include the Mediterranean Sea (Gofas et al., 2014). Ectoparasitic prosobranchs, like O. atlantis, could be able to exploit such corridors adapting to different habitats and communities. This situation might imply a certain plasticity with respect to feeding requirements which could contemplate different hosts.

\section{ACKNOWLEDGEMENTS}

Investigations were carried out in the framework of the "POP'95 Regional Program", aimed to define zonation and distribution of benthic communities in the Strait of Messina. Our thanks go to Marco Taviani (CNR, Bologna, Italy) for the precious suggestions.

\section{REFERENCES}

Andrade, B.G.; Costa, P.M.S. \& Pimenta, A.D. 2011. Taxonomic review of the genus Opaliopsis (Gastropoda: Nystiellidae) from Brazil, with description of a new species. Journal of the Marine Biological Association of the United Kingdom, 91(7): 1561-1566.

Bouchet, P. \& Rocroy, J.P. 2017. Revised classification, nomenclator and typification of gastropod and monoplacophoran families. Malacologia, 61(1-2): 1-526.
Bouchet, P. \& Taviani, M. 1989. Atlantic deep sea Gastropods in the Mediterranean: new findings. Bollettino Malacologico, 25(5-8): 137-148.

Bouchet, P. \& Warén, A. 1986. Revision of the North Eastern Atlantic bathyal and abyssal Aclididae, Eulimidae, Epitoniidae (Mollusca:Gastropoda). Bollettino Malacologico, Supplemento, 2: 297-576.

Braga-Henriques, A.; Carreiro-Silva, M.; Porteiro, F.; Matos, V.; Sampaio, Í; Ocaña, 0. \& Ávila, S.P. 2011. The association between a deep-sea gastropod Pedicularia sicula (Caenogastropoda: Pediculariidae) and its coral host Errina dabneyi (Hydrozoa: Stylasteridae) in the Azores. ICES Journal of Marine Science, 68(2): 399-407. DOI

Brenke, N. 2002. The benthic community of the Great Meteor Bank. In: Oceanography and Ecology of Seamounts - Indications of Unique Ecosystems. ICES ASC CM 2002/M:30, 1-12.

Clench, W.J. \& Turner, R.D. 1952. The genera Epitonium (Part II), Depressiscala, Cylindriscala, Nystiella and Solutiscala in the western Atlantic. Johnsonia, 2(31): 289-356.

Crovato, P. \& Taviani, M. 1985. Nystiella atlantis Clench \& Turner, 1952, from the Pleistocene of Archi (Reggio Calabria: Southern Italy): first fossil record of the subfamily Nystiellinae (Gastropoda, Epitoniidae). Bollettino Malacologico, 21(10-12): 289-294.

de Frias Martins, A.M.; Borges, J.P.; Ávila, S.P.; Costa, A.C.; Madeira, P. \& Morton, B. 2009. Illustrated checklist of the infralittoral molluscs off Vila Franca do Campo. Açoreana, Suplemento, 6: 15-103.

Di Geronimo, I.; Messina, C.; Rosso, A.; Sanfilippo, R.; Sciuto, F. \& Vertino, A. 2005. Enhanced biodiversity in the deep: Early Pleistocene coral communities from southern Italy. In: Freiwald, A. \& Roberts, J.M. (Eds.). Cold-water corals and ecosystems. Berlin, Springer-Verlag. p. 61-86.

Doglioni, C.; Ligi, M.; Scrocca, D.; Bigi, S.; Bortoluzzi, G.; Carminati, E.; Cuffaro, M.; D'Oriano, F.; Forleo, V.; Muccini, F. \& Riguzzi, F. 2012. The tectonic puzzle of the Messina area (Southern Italy): Insights from new seismic reflection data. Scientific Reports, 2: 970. D01

Gofas, S.; Salas, C.; Rueda, J.L.; Canoura, J.; Farias, C. \& Gil, J. 2014. Mollusca from a species-rich deep-water Leptometra community in the Alboran Sea. Scientia Marina, 78(4): 537-553. DOI

Jablonski, D. \& Lutz, R.A. 1983. Larval ecology of marine benthic invertebrates: paleobiological implications. Biological Reviews of the Cambridge Philosophical Society, 58: 21-89.

Leal, J.H. \& Bouchet, P. 1991. Distribution patterns and dispersal of prosobranch gastropods along a seamount chain in the Atlantic Ocean. Journal of the Marine Biological Association of the United Kingdom, 71: 11-25.

Lima, S.F.B. \& Christoffersen, M.L. 2013. Nystiellidae (Gastropoda: Epitonioidea) collected during the REVIZEE Program/Northeast Brazil with descriptions of new species and a checklist of the Family from the Atlantic Coast of South America. American Malacological Bulletin, 31(2): 289-296.

Longhitano,S.G. 2018. Between Scylla and Charybdis (part 1): the sedimentary dynamics of the modern Messina Strait (central Mediterranean) as analogue to interpret the past. Earth-Science Reviews, 18: 59-287. D01

Manousis, T.; Kontadakis, C.; Polyzoulis, G.; Mbazios, G. \& Galinou-Mitsoudi, S. 2018. New marine gastropod records for the Hellenic waters. Journal of Biological Research-Thessaloniki, 25: 6. D01

Mifsud, C. 1993. Recent Mediterranean findings, Opaliopsis atlantis (Clench\& Turner, 1952). La Conchiglia, 25(268): 61-62.

Mifsud, C. 2009. Opaliopsis atlantis (Clench \& Turner, 1952) (Gastropoda: Epitoniidae) found on an actiniarian in the Mediterranean Sea. Bollettino Malacologico, 45(1): 1-3.

Nützel, A. 1998. Uber die Stammesgeschichte der Ptenoglossa (Gastropoda). Berliner Geowissenschaftliche Abhandlungen, ser. Berliner Geowissenschaftliche Abhandlungen, ser E (Palaeobiologie), 26: 1-229. 
Oliverio, M. \& Gofas, S. 2006. Coralliophiline diversity at mid-Atlantic seamounts (Neogastropoda, Muricidae, Coralliophilinae). Bulletin of Marine Science, 79(1): 205-230.

Pierdomenico, M.; Cardone, F.; Carluccio, A.; Casalborne, D.; Chiocci, F.; Maiorano, P. \& D'0nghia, G. 2019. Megafauna distribution along active submarine canyons of the central Mediterranean: Relationships with environmental variables. Progress in Oceanography, 171: 49-69.

Rueda, J.L.; Urra, J.; Aguilar, R.; Angeletti, L.; Bo, M.; García-Ruiz, C.; González-Duarte, M.M.; López, E.; Madurell, T.; Maldonado, M.; MateoRamírez, Á.; Megina, C.; Moreira, J.; Moya, F.; Ramalho, L.V.; Rosso, A.; Sitjà, C. \& Taviani, M. 2019. Cold-Water Coral Associated Fauna in the Mediterranean Sea and Adjacent Areas. In: Orejas, C. \& Jiménez, C. (Eds.). Mediterranean cold-water corals: past, present and future. Coral Reefs of the World. Cham, Springer. v. 9, p. 295-333. D01
Segers, W.; Swinnen, F. \& De Prins, R. 2009. Marine molluscs from the Portuguese province of Madeira. Madeira and Selvagens Archipelago. Monoplacophora, Polyplacophora, Gastropoda, Bivalvia \& Scaphopoda. Belgium, Snoeck Publishers. 612p.

Smriglio, C. \& Mariottini, P. 1999. Molluschi del mar Tirreno centrale. Contributo XII. Segnalazione di due rari Epitoniidae batiali per le coste Laziali. Bollettino Malacologico, 34(9-12): 137-140.

TakanoT.\&KanoY.2014. Molecular phylogenetic investigations of the relationships of the echinoderm-parasite family Eulimidae within Hypsogastropoda (Mollusca). Molecular Phylogenetics and Evolution, 79: 258-269.

Taviani, M.; Angeletti, L.; Dimech, M.; Misfud, C.; Freiwald, A.; Harasewych, M.G. \& Oliverio, M. 2009. Coralliophilinae (Gastropoda: Muricidae) associated with deep-water coral banks in the Mediterranean. The Nautilus, 123(3): 106-112. 